RYSZARD ZIĘBA

Warszawa

\title{
Dziesięć lat po Saint-Malo: próba bilansu Europejskiej Polityki Bezpieczeństwa i Obrony
}

Dziesiąta rocznica porozumienia francusko-brytyjskiego w Saint-Malo przypadła 4 grudnia 2008 r. Właśnie wtedy na spotkaniu na szczycie przywódcy Francji i Wielkiej Brytanii wytyczyli drogę dla rządów państw członkowskich Unii Europejskiej do ustanowienia w roku następnym Europejskiej Polityki Bezpieczeństwa i Obrony (EPBiO). W deklaracji z Saint-Malo stwierdzili, że Unia Europejska „musi mieć zdolność do autonomicznego działania, opartą o wiarygodne siły wojskowe, środki decydowania o ich użyciu i gotowość do czynienia tego w celach odpowiedzi na kryzysy międzynarodowe" . Uzgodnienie to miało przełomowe znaczenie dla podjęcia realizacji jednego z celów Traktatu z Maastricht - potwierdzanie tożsamości UE na arenie międzynarodowej „zwłaszcza poprzez realizację wspólnej polityki zagranicznej i bezpieczeństwa, w tym stopniowe określanie wspólnej polityki obronnej, która [...] mogłaby prowadzić do wspólnej obrony" (art. 2, ex. B) ${ }^{2}$. Przełomowe dlatego, że dotychczas Wielka Brytania odgrywała rolę hamulcowego wysiłków podejmowanych głównie przez Francję i Niemcy na rzecz realizacji tego celu.

Jak więc po dziesięciu latach wygląda realizacja ambitnej deklaracji wydanej w Saint-Malo? Odpowiedź jest zarówno pozytywna, jak i negatywna.

\section{Założenia EPBiO}

Po deklaracji francusko-brytyjskiej Niemcy, sprawujące w pierwszej połowie $1999 \mathrm{r}$. przewodnictwo w Unii Europejskiej i zachodnioeuropejskiej, mogły przygotować propozycje nowych rozwiązań. Znalazły się one w raporcie Prezydencji przedłożonym na posiedzeniu Rady Europejskiej w Kolonii w dniach 3-4 czerwca 1999 r. ${ }^{3}$ W rezultacie przywódcy UE proklamowali ustanowienie Europejskiej Polityki Bezpieczeństwa i Obrony ${ }^{4}$. Program ten rozwinięto w czasie prezydencji Finlandii, a posiedzeniu Rady Europejskiej w Helsinkach w dniach 10-11 grudnia 1999 r. proklamowano tzw. Europejski Cel Zasadniczy/Operacyjny (European Headline Goal), który potem zaczęto

1 From St-Malo to Nice, European Defence; core documents, „Chaillot Paper” (Western European Union Institute for Security Studies), no. 47, Paris, May 2001, s. 8.

2 Zob. Wersja skonsolidowana Traktatu o Unii Europejskiej, „Dziennik Urzędowy Unii Europejskiej”, Seria C, nr 321 E, 29 grudnia 2006, s. 5-36.

3 From St-Malo to Nice, European Defence..., s. 42-45.

4 Ibidem, s. 41-42. W pierwszych dokumentach UE używano nazwy Wspólna Europejska Polityka Bezpieczeństwa i Obrony (Common European Security and Defence Policy). 
określać nazwą Europejski Cel Operacyjny/Zasadniczy 2003 lub nawet jako - Helsiński Cel Operacyjny Zasadniczy. Był to program wojskowego przygotowania Unii Europejskiej do prowadzenia - w ramach $\mathrm{EPBiO}$ - zadań petersberskich. Cel ten zakładał utworzenie najpóźniej do końca 2003 r. sił zbrojnych w rozmiarze korpusu, tj. 50-60 tys. żołnierzy, zdolnych do rozmieszczenia w ciagu 60 dni i prowadzenia wszelkich operacji typu misje petersberskie w przeciagu co najmniej jednego roku. Założono, że te siły szybkiego reagowania mają posiadać, obok wojsk lądowych, także komponenty lotnictwa i marynarki wojennej.

Ważnym uzupełnieniem tych przygotowań do podejmowania przez UE misji petersberskich były decyzje o niewojskowych działaniach w zakresie zarządzania kryzysowego, a następnie utworzenie w maju 2000 r. Komitetu ds. Cywilnych Aspektów Zarządzania Kryzysowego. Dla wdrażania w życie Europejskiej Polityki Bezpieczeństwa i Obrony już w Kolonii zapowiedziano powołanie do życia nowych stałych organów polityczno-wojskowych.

W latach 2000-2001 państwa członkowskie UE dokonały koncepcyjnego doprecyzowania EPBiO. Ministrowie obrony na spotkaniu w Sintrze 28 lutego 2000 r. uzgodnili, że misje petersberskie o większej skali mają być prowadzone w Europie i poza jej obszarem. Alternatywnie postanowili, że Unia może prowadzić jedną długotrwałą operację angażującą niecałe jej siły, a drugą prowadzoną równocześnie w krótszym cza$\operatorname{sie}^{5}$. Na posiedzeniu Rady Europejskiej w Feira (w Portugalii) w dniach 19-20 czerwca 2000 r. określono zasady i warunki uczestnictwa państw członkowskich NATO, nie będących członkami Unii Europejskiej (formuła 15+6) oraz kandydujących do członkostwa w UE (formuła 15 + 15) w działalności na rzecz rozwiązywania kryzysów, a także zasady konsultacji z NATO w sprawach wojskowych.

W czerwcu 2001 r. Rada Europejska na posiedzeniu Göteborgu przyjęła Plan działania policji. Przewidziano w nim trzy priorytety działania: dowodzenie i kontrolę, kryteria treningu i selekcji oraz interoperacyjność ${ }^{6}$. Był to dokument konkretyzujący cywilną część EPBiO.

Wreszcie najważniejszym doprecyzowaniem proklamowanego w Helsinkach Europejskiego Celu Operacyjnego/Zasadniczego było przyjęcie w grudniu 2001 r. przez Radę Europejską w Laeken Planu Działania na rzecz Europejskich Zdolności Obronnych (European Capabilities Action Plan-ECAP) ${ }^{7}$. Jego realizacja ma wypełnić pewne braki (shortfalls) i niedobory (deficiencies/deficits) w budowie zasobów reagowania kryzysowego. Wszystkie prace uściślające proklamowaną w 1999 r. koncepcję EPBiO miały na celu przygotować Unię Europejską do podjęcia w 2003 r. cywilnych i wojskowych operacji reagowania kryzysowego.

Całościowa strategia bezpieczeństwa UE została wypracowana po wejściu w życie Traktatu z Nicei (1 lutego 2003 r.). Składają się na nią następujące dokumenty zatwierdzone przez radę Europejską: A secure Europe in a better world: European security strategy (Europejska Strategia Bezpieczeństwa-ESB), z 12 grudnia 2003 r. oraz wy-

5 Ibidem, s. 94-107.

6 Tekst zob. w: From Nice to Laeken. European defence: core documents, vol. II, (EU ISS), „Chaillot Paper”, no. 51, April 2002, s. 95-102.

7 Tekst ECAP zob. w: ibidem, s. 98-99 i 133-135. 
konawcze programy: nowy Cel Operacyjny/Zasadniczy 2010 (2010 Headline Goal), z 18 czerwca 2004 r.; Plan Dzialania na rzecz Cywilnych Aspektów EPBiO, z 18 czerwca 2004 r.; Cywilny Cel Operacyjny/Zasadniczy 2008 (Civilian Headline Goal 2008), z 17 grudnia $2004 \mathrm{r}^{8}$

W Europejskiej Strategii Bezpieczeństwa znalazło się uzasadnienie prowadzenia przez Unię Europejską własnej polityki bezpieczeństwa i obrony. Jest nim stwierdzenie, że Unia jest oczywistym globalnym graczem i powinna być gotowa dzielić odpowiedzialność za globalne bezpieczeństwo i budowanie lepszego świata. Strategia charakteryzuje środowisko międzynarodowe UE, wskazując na współczesne wyzwania i zagrożenia przed nią stojące, cele strategiczne Unii, oraz wnioski dla zwiększenia efektywności Wspólnej Polityki Zagranicznej i Bezpieczeństwa (WPZiB) i Europejskiej Polityki Bezpieczeństwa i Obrony9.

Generalnie oceniając należy zauważyć, że Europejska Strategia Bezpieczeństwa stanowi całościowy dokument uzasadniający potrzeby i wskazujący na pokaźne możliwości działania UE na rzecz umacniania bezpieczeństwa międzynarodowego. Co jest charakterystyczne dla tego dokumentu podkreśla on potrzebę stosowania różnorodnych instrumentów oddziaływania, zarówno o charakterze wojskowym, jak i cywilnym, a także mocno akcentuje opieranie działań UE na prawie międzynarodowym i efektywnym multilateralizmie. Jest to niewątpliwie charakterystyczna różnica w porównaniu z NATO i unilateralnie prowadzoną polityką zagraniczną USA w czasie prezydentury George'a W. Busha.

\section{Budowanie zdolności wojskowych i cywilnych}

\subsection{Zdolności wojskowe}

Początkowo sądzono w Unii Europejskiej, że dla skutecznego prowadzenia operacji reagowania kryzysowego potrzebne będą pokaźne wojskowe siły szybkiego reagowania, które nie miały stanowić armii europejskiej, a jedynie konglomerat (pool offorces) formacji narodowych. Ich budowanie oparto na dobrowolnym wnoszeniu wkładów przez państwa członkowskie Unii i państwa stowarzyszone (bottom-up approach).

Państwa członkowskie UE (z wyjątkiem Danii, która nie uczestniczy w EPBiO) oraz kraje kandydujące do Unii już w listopadzie $2001 \mathrm{r}$. zadeklarowały w sumie pulę ponad 100 tys. żołnierzy, około 400 samolotów bojowych i 100 okrętów wojennych. Wszystkie te wkłady stanowiły jedynie deklaracje ,na papierze”, a zgłaszane na potrzeby EPBiO siły cechowało występowanie licznych braków (shortfalls) i niedoborów (deficiencies/deficits), które uniemożliwiały ich efektywne wysyłanie w rejony kryzysów.

\footnotetext{
${ }^{8}$ Omówienie tych dokumentów zob. R. Zięba, Europejska Polityka Bezpieczeństwa i Obrony, Wydawnictwo Sejmowe, Warszawa 2005, s. 51-57, 73, 77-78.

9 From Copenhagen to Brussels: European defence: core documents, vol. IV, „Chaillot Paper”, no. 67, December 2003, s. 324-333. Na temat analizy strategii zob.: S. Biscop, The European Security Strategy: A Global Agenda for a Positive Power, Ashgate Publishing Group, Aldershot 2005.
} 
Państwa członkowskie UE zdawały sobie sprawę, że budowanie potencjału wojskowego dla operacji reagowania kryzysowego będzie zadaniem niezwykle trudnym. Dlatego w czerwcu 2000 r. powołały do życia Grupę NATO-UE do Spraw Rozwoju Zdolności Obronnych (EU-NATO Capability Group). Szybko okazało się, że współpraca z NATO nie przynosiła oczekiwanych efektów. Grupa nie zdołała wyjść poza wymianę informacji między obiema organizacjami na temat podejmowanych i realizowanych inicjatyw. W maju 2003 r. zakończono prace nad zaakceptowanym na posiedzeniu Rady Europejskiej w Göteborgu (15-16 czerwca 2001 r.) mechanizmem planowania i przeglądu sił na potrzeby reagowania kryzysowego Unii. Ministrowie obrony przyjęli wówczas dokument zatytułowany Definicja mechanizmu rozwoju zdolności obronnych UE (Defining the EU Capabilities Development Mechanism-CDM), w którym szczegółowo określili zdania w tym zakresie i ich powiązanie z NATO. Mechanizm ten zapowiadał dobrowolny charakter zobowiązań krajów członkowskich, zgłaszających siły na potrzeby EPBiO, harmonizację procesów rozwoju zdolności w UE i NATO. Odpowiadało to ogólnym założeniom polityki bezpieczeństwa państw niechętnych EPBiO (m.in. Polski), zainteresowanych komplementarnością działań UE i NATO. Nie miało to jednak większego znaczenia, gdyż budowanie zdolności reagowania kryzysowego przez UE wpływało hamująco na realizację natowskich programów Inicjatywy Zdolności Obronnych (Defence Capabilities Initiative - DCI) i Praskiego Zobowiazania na Rzecz Zdolności Obronnych (Prague Capabilities Commitment - PCC) ${ }^{10}$.

Proces wypełniania ilościowych i jakościowych braków i niedoborów postępował powoli, a po pierwszych operacjach ,zarządzania kryzysowego” (w Macedonii i w DR Konga) okazało się, że dla ich skutecznego prowadzenia nie są potrzebne wielkie siły, lecz dobrze wyszkolone i bardzo mobilne jednostki wojskowe. W toku trwających od jesieni 2002 r. prac tzw. Koncepcja Szybkiej Odpowiedzi Militarnej, w kwietniu 2004 r. zdecydowano się na tworzenie ,grup bojowych”. Przyjęto, że jednostki tego typu, podobnie do Sił Odpowiedzi NATO (NATO Response Force), mają liczyć do 1500 żołnierzy i być zdolne do przerzucenia w rejon konfliktu najpóźniej w ciagu 15 dni ${ }^{11}$.

W rezultacie na czwartej konferencji planistycznej (22 listopada 2004 r.) rozpoczęto prace nad założeniami planowania strategicznego i przykładowymi scenariuszami w tym zakresie; ministrowie obrony postanowili przygotować tworzone ,grupy bojowe" tak, aby osiągnęły już w 2005 r. wstępną zdolność operacyjną, a pełną zdolność do działania w 2007 r.; uzgodnili też zasady rozlokowywania posiadanych sił (Global Approach to Employability). Ostatnia inicjatywa ma na celu bardziej efektywne wykorzystywanie dostępnych zasobów, mechanizmów i propozycji w zakresie transportu strategicznego, kluczowego elementu realizacji Koncepcji Szybkiej Odpowiedzi Militarnej.

Dalsze prace nad generowaniem zdolności wojskowych były prowadzone przez utworzone w maju 2003 r. grupy projektowe (które zastąpiły działające od lutego 2002 r. panele eksperckie). W ciagu 2003 r., łącznie powstało ich 15. Miały one również cha-

10 DCI została wysunięta na szczycie NATO w Waszyngtonie w kwietniu 1999 r. Miała na celu zwiększenie zdolności Sojuszu do prowadzenia operacji typu out of area. Natomiast PCC stanowiło kolejną inicjatywę przyjętą na szczycie NATO w Pradze w listopadzie 2002 r.

11 Szerzej nt. ,grup bojowych” zob. G. Lindstrom, Enter the EU Battlegroups, „Chaillot Paper”, no. 97, February 2007. 
rakter mało formalny, a wyniki ich prac musiały być akceptowane na odpowiednio wyższym szczeblu przedstawicieli państw członkowskich EU.

\subsubsection{Europejska Agencja Obrony}

Postęp był jednak zbyt powolny, a w czerwcu 2004 r. zdecydowano się na przyjęcie nowego Celu Operacyjnego/Zasadniczego $2010^{12}$ i skoncentrowano się na tworzeniu Europejskiej Agencji Obrony, która rozpoczęła działalność 12 lipca 2004 r. Agencja przejęła główny wysiłek prowadzenia prac nad generowaniem nowych zdolności reagowania kryzysowego. Głównymi kierunkami prac EDA są:

1) Wzmacnianie europejskiego rynku zbrojeniowego. Przygotowany na zlecenie Rady Zarządzającej EDA projekt Międzyrzq̨dowego Reżimu Stymulującego Konkurencyjność Europejskiego Rynku Obronnego. Projekt został zaakceptowany 21 listopada 2005 r. w trakcie posiedzenia Rady UE na szczeblu ministrów obrony i zaczął być wdrażany w życie od 1 lipca 2006 r. Elementami reżimu są dwa dokumenty: Kodeks Postępowania w Zakresie Zamówień Obronnych oraz Kodeks Dobrych Praktyk w Lańcuchu Dostaw. Polska brała udział w wypracowaniu zasad reżimu i chociaż ścierały się opinie jego zwolenników i przeciwników przystapiła do niego na mocy decyzji rządu z 16 maja 2006 r. ${ }^{13}$ Kolejnymi działaniami EDA na rzecz zdynamizowania integracji europejskiego rynku uzbrojenia rozpoczętymi w $2007 \mathrm{r}$. są prace nad trzema europejskimi strategiami tworzenia bazy przemysłowo-technologicznej, badań i uzbrojenia. Widoczne jest to w kolejnych inicjatywach, których wypracowywanie rozpoczęło się w 2007 i 2008 roku. Szczególne znacznie będzie miało wypracowanie Strategii Europejskiej Bazy Przemystowo-Technologicznej, Europejskiej Strategii Badań i Technologii Obronnych oraz Strategii Uzbrojenia. Grupę przygotowująca projekt pierwszej strategii europejskiej bazy przemysłowo-technologicznej tworzyły: Francja, Hiszpania, Holandia, Niemcy, Słowenia, Wegry, Wielka Brytania, Włochy i Polska. Dokument ten został przyjęty przez Radę UE (w formule spotkania ministrów obrony) 19 listopada $2007 \mathrm{r}$.

2) Programy naukowo-badawcze. Francja, Niemcy i Polska zaangażowały się finansowo w rozpoczęty w 2007 r. pierwszy projekt dotyczący pozyskania zdolności $\mathrm{w}$ obszarze ochrony sił zbrojnych (force protection). Ma on na celu zapewnienie żołnierzom ochrony na polu walki np. przed ostrzałem przeciwnika, minami-pułapkami czy nawet przed atakiem z wykorzystaniem broni masowego rażenia.

3) Planowanie rozwoju europejskich zdolności reagowania kryzysowego. Jest ono istotne dla realizacji Europejskiego Celu Operacyjnego 2010, a nawet wykracza poza określony nim horyzont czasowy. Dotychczas EDA wypracowała dwa dokumenty planistyczne. Są to opublikowana w październiku 2006 r. Dlugoterminowa Prognoza w Zakresie Rozwoju Zdolności Reagowania Kryzowego UE (An Initial

12 EU security and Defence: core documents 2004, „Chaillot Paper”, no. 75, February 2005, s. $111-116$.

13 B. Wojna, W kierunku europejskiego rynku uzbrojenia, „Biuletyn PISM”, nr 89 (334), 9 grudnia 2005. 
Long-Term Vision for European Defence Capability and Capacity Leeds - LTV $)^{14}$ i wykonawczy Plan Rozwoju Zdolności (Capability Development Plan - CDP) z czerwca 2008 r. ${ }^{15}$ Można się spodziewać, że ten plan stanowić będzie poważny impuls dla rozwoju przez kraje członkowskie zdolności wojskowych UE. Trudno będzie uniknąc duplikowania podobnych prac planistycznych prowadzonych w NATO. Ale skoro UE zaangażowała się na rzecz budowania własnych zdolności reagowania kryzysowego, to na którymś etapie taka kolizja z planami NATO może nastąpić. Są jednak poglądy wskazujące, że CDP będzie umożliwiać skorelowanie narodowych planów obronnych, a w przypadku rozbieżności priorytetów ujętych w planach rozwoju zdolności UE i NATO, będzie katalizatorem łagodzenia ewentualnych napięć między obu strukturami ${ }^{16}$.

\subsection{Zdolności cywilne}

Unia Europejska postanowiła wygenerować cywilne zdolności potrzebne do prowadzenia operacji rozwiązywania kryzysów. Zgodnie z decyzjami podjętymi przez Radę Europejską na posiedzeniu w Feira w czerwcu 2000 r., zdolności są tworzone w czterech następujących dziedzinach: 1) policja, 2) umacnianie rządów prawa, 3) wzmacnianie administracji cywilnej i 4) ochrona ludności. Główne znaczenie jest przypisywane tworzeniu sił policyjnych gotowych do wysłania w rejon kryzysu. 19 listopada 2001 r. odbyła się w Brukseli ministerialna konferencja planistyczna na temat zdolności policyjnych, na której państwa członkowskie zobowiązały się do przygotowania do 5 tys. policjantów gotowych do wysłania na misję w 2003 r., spośród których 1400 może być rozlokowanych w terenie w ciagu 30 dni.

Od czerwca 2001 r. przygotowaniami policji do podejmowania misji w terenie kieruje Komórka Policyjna działająca w Sekretariacie Generalnym Rady UE. Sprawą tą zajmowano się także na dwóch kolejnych konferencjach planistycznych 19 listopada 2002 r. i 22 listopada 2004 r., a także na spotkaniu szefów policji z państw członkowskich Unii 25 listopada 2004 r. Natomiast przygotowania Unii do angażowania się w pozostałych cywilnych obszarach reagowania kryzysowego są prowadzone z pomocą Wspólnotowego Mechanizmu Ochrony Cywilnej, a więc z udziałem Komisji Europejskiej. Prace te przebiegają dość sprawnie, a ustalona data gotowości Unii do podjęcia cywilnych misji w rejonach kryzysów w 2003 r. została dotrzymana ${ }^{17}$.

Realizując przyjęty przez Radę Europejską w czerwcu 2004 r. Plan Działania na Rzecz Cywilnych Aspektów EPBiO UE prowadzi przegląd swoich zasobów i zdolności reagowania cywilnego. Druga konferencja planistyczna w sprawie zasobów cywilnych

14 EU security and defence: core documents, vol. VI, „Chaillot Paper”, no. 98, March 2007, s. 304-326.

15 Źródło: http://www.eda.europa.eu/documents.aspx>, listopad 2008.

16 P. Hougardy, ESDP Capability Development Plan (CDP), „EDA Bulletin”, Issue 5, July 2007.

17 Zob. Odmienny, sceptyczny pogląd wskazujący na trudności w przygotowaniach UE do prowadzenia cywilnych operacji reagowania kryzysowego: P. Viggo Jakobsen, The ESDP and Civilian Rapid Reaction: Adding Value is Harder than Expected, „European Security”, vol. 15, Issue 3, September 2006, s. 299 i n. 
(odbyta w listopadzie 2004 r.) dostarczyła danych na temat zbiorowych zasobów rozszerzonej do 25 członków Unii i występujących braków. Stwierdzono na niej, że ilościowe cele wyznaczone w czerwcu 2000 r. zostały osiągnięte. Dobrowolne zobowiązania w sprawie wielkości personelu osiągnęły liczbę 5761 policjantów, 631 ekspertów w dziedzinie rządów prawa, 565 w zakresie administracji cywilnej i 4988 w dziedzinie ochrony cywilnej. Ponadto, zgodnie z Planem Działania na Rzecz Cywilnych Aspektów EPBiO, państwa członkowskie Unii - dążąc do zwiększenia rozmiarów działań cywilnych - łącznie zadeklarowały oddelegowanie 505 ochotników do zespołów unijnych obserwacyjnych i 391 ochotników rzeczoznawców dla wspierania specjalnych przedstawicieli UE lub do włączenia ich do wielofunkcyjnych misji. W sumie w listopadzie 2004 r. Unia Europejska dysponowała 12 tys. personelu na potrzeby cywilnych operacji petersberskich, co stanowiło znacznie więcej niż zaplanowano w Feira. Jednak nadal problemem jest zdolność do rozmieszczenia tego personelu w rejonach misji, jego gotowość i przygotowanie do działania; brakuje także opracowanych scenariuszy użycia w misjach zgłoszonych na potrzeby EPBiO policjantów i ekspertów. Znaczy to, że główną troską Unii Europejskiej w zakresie cywilnego zarządzania kryzysowego pozostaje przygotowanie elastycznej i szybkiej odpowiedzi z użyciem posiadanych już zasobów i zdolności.

Unia Europejska, wykonując wytyczne Cywilnego Celu Operacyjnego/Zasadniczego 2008, ustanowiła do końca 2006 r. zespół prawie 100 cywilnych ekspertów (Civilian Response Teams) gotowych do wysłania na misję w ciagu 5 dni. Komórka Policyjna i państwa członkowskie UE, rozwijając koncepcję szybkiego rozmieszczenia policji, wypracowały w ciagu 2006 r. standaryzowane struktury jednostek policyjnych przeznaczonych do wykonywania zadań w terenie (Integrated Police Units i Formed Police Units). Na ministerialnej konferencji planistycznej (Civilian Capabilities Improvement Conference 2006) zorganizowanej w Brukseli 13 listopada 2006 r. wskazano, że państwa członkowskie Unii powinny się skoncentrować na przygotowaniu kilku brakujących elementów reagowania cywilnego, zwłaszcza w kontekście planowanej misji w Kosowie. Za takie uznano następujące kategorie personelu cywilnego: sędziowie i prokuratorzy, personel więzienny, oficerowie policji i kontroli granicznej ${ }^{18}$. Po długich kontrowersjach z NATO, w maju 2005 r. w Sztabie Wojskowym UE ustanowiono Komórkę Cywilno-Wojskową mogącą tworzyć wspólne centra operacyjne do planowania i kierowania autonomicznymi operacjami cywilno-wojskowymi UE. Rozpoczęła ona działalność w styczniu $2007 \mathrm{r}$.

Ważną inicjatywą jest projekt stworzenia żandarmerii europejskiej. Na nieformalnym spotkaniu ministrów obrony UE w Noordwijk (w Holandii) 17 września 2004 r. Francja, Włochy, Hiszpania, Portugalia i Holandia podpisały deklarację intencji w sprawie powołania Sił Żandarmerii Europejskiej (European Gendarmerie Force - EGF/EUGENDFOR). Koncepcję tych sił mających służyć stabilizowaniu sytuacji po zakończonych konfliktach zaproponowała Francja na nieformalnym spotkaniu ministrów obrony państw UE w Rzymie w dniach 3-4 października 2003 r. Siły te mają docelowo liczyć 800-900 żandarmów, których można będzie rozmieścić w terenie

18 EU security and defence: core documents, vol. VI, s. 359-374. 
w ciagu 30 dni, a możliwe będzie powiększenie ich liczebności do 2300 żandarmów stojących w odwodzie). Inicjatywa stworzenia Sił Żandarmerii Europejskiej została poparta w dniu 22 listopada 2004 r. przez Radę UE, stając się od tego czasu wspólnym przedsięwzięciem Unii Europejskiej. Kwatera tych sił (złożona z oficerów z pięciu krajów uczestniczących) została ulokowana w Vicenza (Włochy), a rozpoczęła działalność 15 września 2005 r. Oficjalnie traktat ustanawiający utworzenie EGF został podpisany przez pięć państw 18 października 2007 r. EGF osiągnęły pełną zdolność operacyjną już 15 grudnia 2007 r., rozpoczynając w tym dniu swoją pierwszą misję przejmując dowodzenie Zintegrowanej Jednostki Policyjnej w Sarajewie, działającej w ramach misji EUFOR „Althea”. Siły Żandarmerii Europejskiej są w pierwszej kolejności przeznaczone na potrzeby misji reagowania kryzysowego prowadzonych przez Unię Europejska, mogą także być wykorzystywane przez NATO, ONZ, OBWE lub doraźne koalicje. Polska posiadająca mającą status militarny Żandarmerię Wojskową uzyskała status partnera EGF.

Ogólnie należy zauważyć, że angażowanie się Unii Europejskiej w prowadzenie cywilnych operacji rozwiązywania kryzysów stanowi wyraz jej szerszych ambicji odgrywania niekonwencjonalnej roli cywilnego aktora polityki bezpieczeństwa oraz stabilizowania i budowania pokoju przez promowanie demokracji i prosperity ${ }^{19}$. EPBiO zatem, wbrew swojej nazwie, sugerującej wyłączny związek z tradycyjnym zmilitaryzowanym pojmowaniem bezpieczeństwa, łączy środki prewencyjne oraz wojskowe środki reagowania kryzysowego z cywilnymi (w tym ekonomicznymi z I filaru Unii); dzięki temu ma szansę stać się nowym i wielostronnym przedsięwzięciem potwierdzającym tożsamość Unii Europejskiej jako kompleksowego aktora sceny międzynarodowej ${ }^{20}$.

\section{Operacje reagowania kryzysowego}

Unia Europejska, po przejęciu w latach 1999-2001 przejęciu części operacyjnej UZE, może w ramach EPBiO prowadzić poza obszarem jej państw członkowskich następujące rodzaje misji petersberskich: operacje humanitarne i ratownicze, rozjemcze misje pokojowe oraz zadania bojowe opanowywania sytuacji kryzysowych, w tym przywracania pokoju. Gdyby wszedł w życie Traktat z Lizbony (podpisany 13 grudnia 2007 r.) katalog tych operacji zostałby poszerzony o: wspólne działania rozbrojeniowe, misje wojskowego doradztwa i wsparcia oraz wspieranie państw trzecich w zwalczaniu terroryzmu (jako oddzielne misje lub element pozostałych misji, art. 28b). UE

19 Szerzej zob. S. Rynning, Providing Relief or Promoting Democracy? The European Union and Crisis Management, „Security Dialogue”, vol. 32, no. 1, March 2001, s. 87-101.

20 Szerzej zob. R. Zięba, Unia Europejska jako aktor stosunków międzynarodowych, Wydawnictwo Naukowe Scholar, Warszawa 2003, zwłaszcza rozdz. IX. Por.: E. Tuomioja, Sécurié et defense (le point de vue finlandais sur la PECSD), „Défense nationale”, n 3, mars 2001, s. 9; Ch. Hill, The EU's Capacity for Conflict Prevention, „European Foreign Affairs Review”, vol. 6, Issue 3, s. Autumn 2001, s. 331-333; K. Becher, Has-Been, Wannabe, or Leader: Europe's Role in the World after the 2003 European Security Strategy, „European Security” 2004, vol. 13, Issue 4, s. 345 i n.; J. McCormick, The European Superpower, Palgrave Macmillan, Basingstoke 2007, s. 78-83. 
zaczęła prowadzić operacje reagowania kryzysowego w 2003 r. Formalnie są one dzielone na dwa rodzaje jako operacje wojskowe i cywilne.

\subsection{Misje wojskowe}

Operacje wojskowe stanowią bardziej skomplikowane i wymagające przedsięwzięcia prowadzone $\mathrm{z}$ udziałem od kilkuset do kilku tysięcy żołnierzy. Zgodnie z przyjętym w listopadzie 2005 r. Katalogiem Wymagań (stanowiącym rozwinięcie Mechanizmu Rozwoju Zdolności - CDM) mogą one obejmować następujące rodzaje działań:

- pomoc humanitarna polegająca na zapobieganiu konfliktom, ochrona obozów uchodźców, pracowników misji humanitarnych, konwojów i magazynów z pomocą humanitarną;

- ewakuacja personelu cywilnego z terenów zagrożonych w trakcie walk zbrojnych;

- zapobieganie wybuchowi konfliktów (rozbrojenie wrogich sobie stron, wymuszanie przestrzegania embarga, wymuszanie i nadzorowanie nieproliferacji);

- działania stabilizacyjne i zakresu odbudowy (utrzymanie bezpieczeństwa i porządku publicznego, monitorowanie przestrzegania rozejmów i wycofania wojsk, doradztwo wojskowe w sprawach budowy instytucji demokratycznych i struktur państwowych oraz reformy sektora bezpieczeństwa);

- rozdzielenie sił skonfliktowanych stron (demonstracja siły, blokada, bezpośrednie działania wojskowe, ochrona dróg zaopatrzenia $)^{21}$.

Unia Europejska dotychczas pomyślnie przeprowadziła trzy operacje wojskowe: w Macedonii (Concordia, III-XII 2003), w DR Konga (Artemis, VI-IX 2003) i ponownie w RD Konga (EUFOR Congo, VII-XI 2006). Obecnie kontynuuje dwie duże operacje w Bośni i Hercegowinie (EUFOR Althea, od grudnia 2004 r.) oraz w Czadzie i Republice Środkowoafrykańskiej (EUFOR Tchad/RCA, od marca 2008 r.), a w listopadzie $2008 \mathrm{r}$. podjęła decyzję o rozmieszczeniu morskiej operacji zwalczania piractwa u wybrzeży Somalii (EU NAVFOR ,Atalanta”).

Wszystkie operacje wojskowe UE, podobnie jak cywilne, są prowadzone na podstawie mandatu Rady Bezpieczeństwa ONZ i w porozumieniu z tą organizacją.

Pierwsza operacja wojskowa w ramach EPBiO podjęta była z opóźnieniem spowodowanym trudnościami w porozumieniu się z NATO (w formule Berlin Plus) w sprawie korzystania z zasobów planistycznych Sojuszu. Operacja ta miała za zadanie stabilizowanie sytuacji w Macedonii i ułatwianie procesu pokojowego między Macedończykami a ludnością albańską; zastąpiła ona wcześniej prowadzoną w tym kraju misję natowską. W operacji Concordia wzięło udział tylko 350 żołnierzy z 13 państw UE i 14 innych krajów. Zgodnie z regułami ustalonymi wcześniej między UZE a NATO kierowanie operacją powierzono zastępcy dowódcy wojsk NATO w Europie, niemieckiemu admirałowi Reinerowi Feistowi. Natomiast dowódcą polowym (faktycznym) był Francuz, generał Pierre Maral. Operacja ta wbrew licznym pesymistom zakończyła się sukcesem, a po pół roku można ją było zastąpić misją policyjną (Proxima).

21 J. J. Anderson, Armed and Ready? The EU Battlegroups Concept and the Nordic Battlegroup, Swedish Institute for European Policy Studies, Stockholm 2006, s. 34. 
Prawdziwym sprawdzianem Unii Europejskiej w prowadzeniu wojskowych operacji reagowania kryzysowego okazała się pomyślnie przeprowadzona, samodzielnie bez porozumiewania się z NATO, operacja Artemis w DR Konga. Stanowiła ona duże przedsięwzięcie wojskowe przeprowadzone siłami ok. 1800 żołnierzy. Jej celem było wspieranie prowadzonej w tym kraju misji pokojowej ONZ (MONUC). Państwem wiodącym w tej operacji była Francja, a dowódcami francuscy generałowie (naczelnym - Bruno Neveux a polowym - Jean-Paul Thonier). Chociaż trwający ok. dwa i pół miesiąca pobyt żołnierzy z UE w Kongu nie uzdrowił sytuacji, to jednak UE wykazała, że jest zdolna samodzielnie prowadzić duże operacje wojskowe. Bezpośrednim doświadczeniem wyniesionym z tej misji było uświadomienie sobie potrzeby przejścia do tworzenia mobilnych, dobrze wyszkolonych i uzbrojonych, grup bojowych”. Decyzję o tych nowych siłach natychmiastowego reagowania UE podjęła wiosną następnego roku.

Trzecią zakończoną operacją wojskową w ramach EPBiO była misja EUFOR Congo. Jej celem było wspieranie sił pokojowych MONUC w organizowaniu wyborów w DR Konga. Wzięło w niej udział ok. 1100 wojskowych obserwatorów, a dodatkowo w odwodzie w Gabonie stacjonowało 1300 żołnierzy gotowych przyjść z pomocą siłom bezpośrednio prowadzącym operację w Kongu. Naczelnym dowódcą operacji był francuski generał Christian Damay, a dowódcą polowym generał niemiecki Karlheinz Viereck. Operacja ta stanowiła kolejne duże przedsięwzięcie wojskowe UE.

Największą wojskową misją petersberską Unii Europejskiej jest operacja EUFOR Althea w Bośni i Hercegowinie. Zastapiła ona stacjonujące w tym państwie, dowodzone przez NATO, siły SFOR. Jej celem jest kontynuowanie nadzorowania wykonania przez strony zakończonego w 1995 r. konfliktu międzyetnicznego. Początkowo w operacji zaangażowano ok. 6,5 tys. żołnierzy z 24 państw Unii i z 9 innych krajów. Wraz z dokonującą się normalizacją w Bośni i Hercegowinie do połowy 2007 r. zredukowano cały kontyngent do 2,5 tys. żołnierzy. UE utrzymuje jednak poza w swoich krajach członkowskich gotowe do wsparcia siły (,grupy bojowe”). W listopadzie 2007 r. Rada UE zatwierdziła dokonaną rekonfigurację sił zaangażowanych w operacji oraz podkreśliła, że UE utrzyma swoją obecność w Bośni i Hercegowinie tak długo jak to będzie potrzebne.

Operacja wojskowa w Bośni i Hercegowinie jest prowadzona na podstawie porozumień z NATO i przy wykorzystaniu jego zasobów wojskowych. Ściśle współdziała z misją policyjną (EUPM), Misją Obserwacyjną UE (EUMM), Międzynarodowym Trybunałem ds. Zbrodni Wojennych w byłej Jugosławii (ICTY) oraz ze specjalnym przedstawicielem UE ds. Bośni i Hercegowiny, który jest koordynatorem całokształtu zaangażowania Unii na rzecz ustanowienia trwałego pokoju w tym kraju. Pierwszym naczelnym dowódcą operacji został Brytyjczyk, generał John Reith, zastępca dowódcy wojsk NATO w Europie (zgodnie z porozumieniem w formule Berlin Plus), a dowódcą polowym także Brytyjczyk A. David Leakey; obecnie stanowiska te zajmują odpowiednio: brytyjski generał John C. McColl (od października 2007 r.) i hiszpański generał Ignacio Martín Villalaín (od grudnia 2007 r.).

Po długich przygotowaniach wiosną 2008 r. Unia Europejska zaczęła rozmieszczać operację wojskową w Czadzie i Republice Środkowoafrykańskiej, a pełna zdolność operacyjna misja osiagnęła dopiero 15 września 2008 r. Misja ta (EUFOR Tchad/RCA) 
ma bezpośredni związek z katastrofalną sytuacją humanitarną wywołaną wojną w sudańskiej prowincji Darfur. Jej celem jest, przyczynianie się wspólnie z operacją ONZ (MINURCAT) do: ochrony ludności cywilnej, w tym zwłaszcza uchodźców, ułatwianie dostaw pomocy humanitarnej, ochrona personelu ONZ, magazynów, infrastruktury oraz zapewnianie swobody poruszania się personelu ONZ i organizacji humanitarnych. Jest to bardzo wymagająca operacja, zwłaszcza ze względu na trudną sytuację na miejscu, olbrzymi obszar i braki infrastruktury drogowej. W operacji ma wziąć udział 3700 żołnierzy z 14 państw UE i 22 innych; ma to być najbardziej wielostronna operacja wojskowa UE. Naczelnym dowódcą operacji został mianowany Irlandczyk generał Patric Nash, a dowódcą sił UE - Francuz, generał Jean-Philippe Ganascia. Żołnierze uczestniczący w operacji mają prawo użycia siły w razie potrzeby, ale mają zachowywać się neutralnie wobec „stron”.

\subsection{Misje cywilne}

Większość operacji reagowania kryzysowego UE stanowią misje. Zostały zapoczątkowane 1 stycznia 2003 r. misją policyjną w Bośni i Hercegowinie (EUPM); misja ta jest obecnie kontynuowana. Od tego czasu UE prowadzi operacje monitorujące i doradcze z udziałem ekspertów w różnych sektorach działalności państw zdestabilizowanych.

Celem misji monitorujących jest obserwowanie, nadzorowanie i doradzanie policji w kraju rozlokowania. W większości przypadków misje te są wykonywane przez policję. Taki charakter poza wspomnianą już misją w Bośni i Hercegowinie miała dotychczas zakończona misja w Macedonii (EUPOL Proxima, XII 2003-XII 2005). UE prowadzi od grudnia 2005 r. misję monitorowania ruchu na przejściu granicznym między Izraelem a Autonomią Palestyńską (EU BAM Rafah), a w czerwcu 2007 r. rozpoczęła misję w Afganistanie (EUPOL Afganistan). Specyficzny charakter ma rozpoczęta 1 października 2008 r. misja monitorująca w Gruzji (EUMM in Georgia), w której zadania typowe dla policji wykonują nieuzbrojeni obserwatorzy cywilni. Operacje mają średnie rozmiary pod względem liczebności; w Bośni i Hercegowinie zaangażowano ok. 500 policjantów, ale od początku $2006 \mathrm{r}$. ich liczbę zredukowano do 170, wspomaganych przez 28 pracowników cywilnych; w Macedonii-ok. 200 policjantów, w Rafah - ok. 70, w Afganistanie ok. 200 policjantów, a w Gruzji ok. 340 osób personelu, w tym ponad 200 nieuzbrojonych cywilnych obserwatorów w terenie.

Misje doradcze za cel mają udzielanie wsparcia ekspertów, doradztwo i szkolenie w „,ywilnych” dziedzinach funkcjonowania państw przyjmujących misje. Są to tzw. misje „rządów prawa”, obejmujące m.in.: wspieranie i reformowanie wymiaru sprawiedliwości, policji, zwiększanie efektywności służb granicznych i celnych, pomoc w reformowaniu ,sektora obronnego", a także obserwowanie przez cywilów przestrzegania porozumień o zaprzestaniu walk (w Gruzji). Misje te zazwyczaj składają się z kilkunastu lub kilkudziesięciu ekspertów, wśród których mogą być także wojskowi. Dotychczas Unia Europejska prowadziła cztery misje doradcze w: Demokratycznej Republice Konga (doradztwo w tworzeniu policji, EUPOL Kinshasa, IV 2005-VI 2007), w Gruzji (misja „rządów prawa”, pomoc w umacnianiu wymiaru sprawiedliwości 
i reformowaniu systemu prawnego, EUJUST Themis, VII 2004-VII 2005), w Macedonii (doradcza policyjna EUPAT, XII 2005-VII 2006); w Indonezji w prowincji Aceh (misja nadzorująca rozbrojenie walczących stron, monitorowanie sytuacji w zakresie praw człowieka, zmian legislacyjnych i reintegracji społecznej i politycznej separatystów ze zbuntowanej prowincji, AMM, IX 2005-XII 2006).

Obecnie Unia Europejska prowadzi misje doradcze w Mołdowie i na Ukrainie (pomoc graniczna dla obu państw Border Assistance Mission, od grudnia 2005 r.), w Palestynie (wspieranie policji EU COPPS, następnie EUPOL-COPPS, od kwietnia 2005), w krajach UE zintegrowaną misję rządów prawa dla Iraku (EUJUST LEX od lipca 2005 r.); misję doradztwa i pomocy w reformowaniu wojskowego sektora bezpieczeństwa w DR Konga (EUSEC - RD Congo, od czerwca 2005 r.); misję doradztwa i pomocy w reformowaniu policji i wymiaru sprawiedliwości w DR Konga (EUPOL RD Congo, od lipca 2007 r.); udziela pomocy logistycznej i doradczej dla misji Unii Afrykańskiej AMIS II w Sudanie (w prowincji Darfur, od lipca 2005 r.); misję doradczą w reformowaniu sektora bezpieczeństwa w Gwinei-Bissau (EU SSR Guinea-Bissau, od czerwca 2008 r.). W lutym 2008 r., w związku z ogłoszeniem niepodległości przez Kosowo, UE ustanowiła misję rządów prawa dla tego kraju (EULEX KOSOVO). Jest to duża wielofunkcyjna misja cywilna (policjanci, eksperci od wymiaru sprawiedliwości i służb celnych); w końcu 2008 r. liczyła ok. 500 ekspertów międzynarodowych i ok. 200 osób personelu lokalnego, a jej rozmiary mają być powiększone odpowiednio do 1900 i 1100 osób; przewidziano także możliwość rozmieszczenia w Kosowie dodatkowo 300 policjantów i pograniczników, jeśli taka potrzeba wystąpi. Szefem misji został Francuz - Ives de Kermabon.

Generalnie misje doradcze są niewielkie i składają się z personelu od kilkunastu do kilkudziesięciu ekspertów międzynarodowych, zwykle wspomaganych administracyjnie przez personel miejscowy.

\section{Wyzwania stojące przed EPBiO}

Francja, sprawująca w drugiej połowie 2008 r. przewodnictwo w Unii Europejskiej, w opublikowanej wcześniej Białej księdze na temat obrony i bezpieczeństwa narodowego, zaproponowała by Unia była zdolna prowadzić dwie lub nawet trzy wojskowe operacje reagowania kryzysowego równocześnie, a równocześnie kilka operacji cywilnych $^{22}$. Można stwierdzić, że obecnie tak się dzieje. Problem tkwi jednak w pytaniu, czy EPBiO jest skuteczna?

Polityka ta ma charakter międzyrządowy, a to sprawia, że państwa członkowskie UE powinny zdecydować się czego od EPBiO oczekują, podobnie jak od całej WPZiB?

Pierwszą kwestią jawi się zagadnienie rozmiarów, intensywności i siły podejmowanych przez Unię wojskowych operacji reagowania kryzysowego. Trzeba zauważyć, że

22 Défense et Securité nationale: Le livre blanc, Odile Jacob/La Documentation Française, Paris, 17 Juin 2008, cz. I, s. 89. Zob. także D. Fiott, The French White Paper on Defence and National Security: Peacebuilding, NATO, Nuclear Weapons and Space, „European Security Review”, no. 40, September 2008, s. 7. 
państwom członkowskim brakuje wspólnej woli prowadzenia takich działań, zwłaszcza w odległych od Europy regionach świata.

Drugim wyzwaniem jest potrzeba wzmocnienia istniejących zasobów planistycznych. Ponieważ Unia podejmuje operacje wielofunkcyjne od początku 2007 r. wykorzystuje w tym celu personel cywilny i wojskowy (Komórkę Cywilno-Wojskową usytuowaną w Sztabie Wojskowym UE). Obecnie UE dysponuje zaledwie 8 wojskowymi i 60 cywilami zaangażowanymi w procesie planowania, podczas gdy w NATO jest ich około 3000. To sprawia, że podejmując operacje wojskowe musi polegać na dowództwach narodowych lub na Kwaterze Głównej NATO. Natomiast sztaby te nie mogą stosować całościowego podejścia łączącego środki militarne i cywilne. Niewątpliwie wzmocniona struktura planistyczna UE mogłaby czynić to bardziej efektyw$n^{23}{ }^{23}$. Dlatego istnieje potrzeba wzmocnienia struktury planistycznej UE. Idące w tym kierunku propozycje prezydencji francuskiej, powodują obawy proatlantycko nastawionych państw członkowskich UE.

Trzecim problemem, przed jakim nadal stoi EPBiO jest brak adekwatnych do operacji reagowania kryzysowego zasobów militarnych i cywilnych. W trakcie prowadzonych operacji te braki kompensowane są przez współpracę z NATO i ONZ. Nadal jest aktualny cel postawiony w 1999 r. o potrzebie stworzenia sił szybkiego reagowania w sile 60 tys. żołnierzy. Do tego też nawiązuje propozycja Francji zawarta w Białej księdze z $2008 \mathrm{r}$. sugerująca stworzenie silnych sił interwencyjnych o tej wielkości złożonych z trzech rodzajów wojsk: lądowych, lotniczych i morskich ${ }^{24}$. Jedną z dróg do tego prowadzących może być przyspieszenie realizacji dotychczas wypracowanych na forum UE planów, w tym specjalizacji i wspólnego wykorzystywania części posiadanych przez państwa członkowskie zasobów. Warto w tym miejscu przypomnieć, że brytyjski premier w Saint-Malo nie zgodził się na tworzenie wspólnej europejskiej armii. Czyli zasoby i zdolności interwencyjne UE mają być generowane nie jako jednolita armia, lecz konglomerat sił.

Konkludując należy stwierdzić, że porozumienie francusko-brytyjskie z Saint-Malo otworzyło drogę do uruchomienia przez Unię Europejską EPBiO. Nowa polityka okazała się korzystna dla świata, a także podniosła znaczenie międzynarodowe UE. Ujawnione niedostatki i istniejące wyzwania powodują, że nadal istnieje potrzeba ścisłego współdziałania Francji i Wielkiej Brytanii, jako czołowych mocarstw europejskich, dla pomyślnego jej rozwoju. Tylko bowiem pod tym warunkiem wszystkie państwa członkowskie Unii Europejskiej będą miały szansę pomyślnego odnajdywania się w EPBiO i jej dalszego rozwijania.

${ }^{23}$ Por. analizę przygotowaną przez eksperta Instytutu Studiów nad Bezpieczeństwem UE: D. Keohane, 10 years after St. Malo, „Issues”, (EU Institute for Security Studies), no. 27, October 2008, s. 6.

${ }_{24}$ Défense et Securité nationale: Le livre blanc, s. 89. 
